\title{
Indonesian Public Diplomacy: Preserving State Existence through Sharing of Indetities to Gain Mutual Understanding
}

\author{
Iva Rachmawati \\ Universitas Pembangunan Nasional "Veteran" Yogyakarta
}

\begin{abstract}
This article places public diplomacy as an effort to preserve state's existence in the international relations as well as to share identity in order to achieve mutual understanding by state and non-state actors. The conception of public diplomacy over the years has placed public diplomacy on the narrow framework of the state's efforts to build a positive image. As a result, such efforts are ignorant of the important efforts of non-state actors in building a fundamental thing for the existence of a state, its identity. Through some historical facts, this article shows that public diplomacy is an effort not only held by the state but also non-state actors in communicating their identity. Both actions are within the public diplomacy of state design or done independently. State domination sometimes limits the movement of non-state actors, but on the contrary in the current era of openness provides wider opportunities for non-state actors to play a better and more independent role in preserving their existence as well as relations among citizen
\end{abstract}

Key Words: public diplomacy, state and non-state actors, maintain the existence, sharing identity, mutual understanding.

Artikel ini menempatkan diplomasi publik sebagai upaya memelihara eksistensi negara dalam pergaulan internasional sekaligus berbagi identitas dalam rangka mencapai saling kesepahaman yang dilakukan oleh negara dan aktor non negara. Konsepsi diplomasi publik selama ini telah menempatkan diplomasi publik pada kerangka sempit upaya negara dalam membangun imagi positif. Akibatnya, justru upaya tersebut abai terhadap upaya penting aktor non negara dalam membangun hal mendasar bagi eksistensi sebuah negara, identitas dirinya. Melalui beberapa fakta sejarah, artikel ini menunjukkan bahwa diplomasi publik merupakan upaya yang tidak saja dilakukam oleh negara tetapi juga aktor non negara dalam mengomunikasikan identitas dirinya. Baik dalam kerangka diplomasi publik desain negara maupun dilakukan secara mandiri. Dominasi negara terkadang membatasi pergerakan pelaku non-negara, namun sebaliknya di era keterbukaan saat ini memberikan kesempatan lebih luas bagi pelaku non-negara untuk memainkan peran yang lebih baik dan lebih mandiri dalam menjaga eksistensi serta hubungan antar warga.

Kata-kata kunci: diplomasi publik, aktor negara dan non negara, memelihara eksistensi, berbagi identitas, saling kesepahaman. 
The big influence of the rationalist approach in constructing diplomacy forces positioning diplomacy into an instrument to attain the national interest that merely refers to economic and security interests (Hans Tuch 1990, 3). Collaboration through dialogs and mutual understanding then become the main priority of the goal of public diplomacy. Public Diplomacy itself grew to be an important effort of a state to persuade government and public outside the state about the positive image of the state. These kinds of effort then often lead the public diplomacy merely to not more than a nation branding effort. In Indonesia, the efforts of constructing positive image become a part of elite contestation in influencing the direction of Indonesian foreign politics (Ziyad Falahi 2012).

The effort to give a certain label or image made public diplomacy not far different from political propaganda which Berridge (2010) calls only have a plastic surgery but the substance is not far different. The consequence is that public diplomacy becomes the state's domain only. Meanwhile, domestic dimension become the passive subject of the whole construction of public diplomacy. As a passive subject means that thay are under the domination of the state both in interpreting the international situation and in carrying out the public diplomacy.

Placing public diplomacy in this framework has neglected the significant meaning of the existence of the state itself. The goal of public diplomacy for constructivist lies not only on the national's interest because it believes that the national's interest will always change in line with the change in state identity because of the interactions between states. It is the identity which will determine or interpret and give meaning to the material capability and the behavior of a nation's institution (Henry R. Nau $2009,44)$. The state's identity is formed not only because of its interaction with other actors outside the country but also as a result of the interaction of the people within their own state. There are some constructivists who emphasize that actor identity is the result of interaction with other actors in the structure, but others believe that identity is autonomous. Autonomous identities according to Nau come from the ability of actors to criticize the social discourse in which they are involved (Henry R. Nau 2009, 45). For Hopf, it is the domestic identity that forms the cognitive structure that determines threats, opportunities, enemies, alliances, etc (Ted Hopf 2002, 16). Actors are tied to speech, communication skills to claim truth, to influence and persuade and learn from one another. In this case, material capability gives influence in mastering the process of forming the structure (norm). It is through this process that each actor shares an identity that defines who they are and who the other is. And through this process also, a state understands others according to the identity it attributes to them, while simultaneously reproducing its own identity through daily social pratice (Ted Hopf 1998, 175).

This article is written to show that public diplomacy can not be positioned within the framework of the state's efforts to gain only its economic and security interests, thus building the image of the state and the perception of the international community to be the sole purpose of public diplomacy. Public Diplomacy then holds a larger task than reaching the national interest through the development of a particular perception or image, that is to nurture national identity by communicating identity and / or sharing comoon identities in order to foster mutual understanding. Such efforts then become not only the domain of the state but also the non-state actors through the networks they have. In addition to looking at state efforts in organizing public diplomacy, this article is written also to look at the role of non-state actors in the practice of sharing 
identity and maintaining relations between countries. Articles are written in three periods to see the state's efforts as well as how far and how non-state actors play a role in public diplomacy.

\section{Public Diplomacy as the Expression of System Differentiation in Luhman's Social Systems}

Relations that are connected massively give every actor a chance to make a relation based on his/her interest. However, the interest should be based on the perception toward his own self identity. It is the self identity that becomes the context of a number of interests, perceptions, and actions. Self Identity serves as the bond for perceptions and actions was constructed from awareness of becoming a part of a system that grew in the movement process of a social system or a nation. The awareness is constructed and developed from the meanings which is shared in a social system through a communication process. The awareness could take part in a communication to construct a system as long as it functions as one of the elements that take a role in its autopoeietic character.

The understanding of a nation through Luhman's social system framework positioned diplomacy as communication of a system with its surrounding and/or with other systems with some subsystems inside. Communication is not perceived as a communicative action that result in an understanding but as an action that become an exactness, as a condition of possibility for the existence of the sysem itself which has an autopietic feature. Public diplomacy then becomes a bridge for the expressions of system differentiation (related to its existence) and to communicate its identity to other political entities in order to achieve mutual understanding (Niklas Luhmann 1995).

In a system, there are some subsystems that work by duplicating the system's work. The great access toward the issues outside the system enable the subsystems to run the same pattern as the system in adopting information and executing the communication. The awareness element as a part of the system ties the subsystem to move in the system and make it a part of motivation. The subsystem's self refence effort make the response of the issues or changes from different environment from one subsystem with other subsystem inside the system. This can be helpful in reading some different responses showed by the domestic dimension toward intermestic issues. Attitudes and narration that become the responses toward some issues are not always the same even they take contradictive forms. This shows that the interactions done by the subsystem are not always in the same form. However, the differences in responding are still on the same bond, which is the awareness of being a part of a system.

Referring to communication as the effort of a system and its subsystem to construct a relationship with the environment and at the same time nurture its self identity, then it is understandable that diplomacy is not only an effort to stick an image but also an effort of the state and domestic dimension in which it influences the relationship between countries that are bound by their identity as a social system namely a state. Public diplomacy is about building relationships: understanding the needs of other countries, cultures and peoples; communicating our points of view; correcting misperceptions; looking for areas where we can find common cause (Mark Leonard, Catherine Stead and Conrad Sweming 2002, 8-9). 
Therefore, the role of subsystem or domestic dimension in construct the relation and nurture self identity is significant in public diplomacy building. Their capability in communication strategy (Geoffrey Cowan and Amelia Arsenault 2008), building network and transforms a number of ideas (Brian Hocking 1998) are proofs that they are capable in influencing public diplomacy. Separating them is impossible because the fact that all people are interconnected (interconnected realities) (Hans Tuch 1990, 3). Even Snow declares that public diplomacy should be done by domestic actors than by the government (Nancy Snow 2009, 4). The ability of domestic public makes them more considered as agents in public diplomacy besides the state. Some researches show that domestic public or domestic dimension could mobilize the citizens fight against MNC (Po-Chi Chen 2012), give contribution to the reconciliation between countries independently (Sajjad Malik 2014) and becomes a bridge for the citizens of the countries that do not have diplomatic representatives (Karolina Kupinska 2010).

The autonomy of domestic public in administerring the relation between countries promotes researches on public diplomacy positioning them equal to the states. Terminologies like 'New Public Diplomacy' (Jan Melissen 2011), 'Integrative Public Diplomacy' (Brian Hocking 2012), 'Dialogue Based Public Diplomacy' (Shaun Riordan 2004) and Double Edge Diplomacy (Moravscik, 1993) refer to the importance of positioning the domestic public as the sate's partners and the importance of the cooperation between them. However, Melissen reminds that the position of non-state actors is subordinant to the country. The term government driven is used by Melissen to describe whatever are the force of the influence of the non-state actors, the state has to be capable of becoming the main control of every diplomacy done (Jan Melissen 2011).

In the other hand, La Porte through his 'intermestic non-state actors' reminds that the ability of domestic dimension in constructing relationshis between civil citizens in various countries enable them to come as a mediator and work autonomously (Teresa La Porte 2012). However, not all non-state actors could become the actors of public diplomacy. Only those who have public supports have legitimacy and efficacy (Teresa La Porte 2012). One of indicators of that matter is that an actor gains support from the public through a set of actions, such as supporting the movement through donation. They also have to be able to represent public (at least some parts of the public) although it does not alays refer to the number, they should be institutionalized and could coordinate themselves and have political goals.

\section{Diplomacy of Independence: an Effort of System Differentiation to Maintain its existence as an Independent Country}

Diplomacy of Independence could be a historical fact in perceiving how public diplomacy could be an effective way in maintaining the national identity and influence the relationship between countries. Earliest time of Independence is a crucial time for a new country including Indonesia to get aknowledgement from other countries in the world either de facto or de yure. However, the earliest time of independence has a special challenge for Indonesia, because the diplomatic effort was still viewed by the elites as a less strategic effort; remember that Indonesia at that time had to face the Dutch effort to get back to rule Indonesia. 
The efforts to introduce the identity of Indonesia as a new independent country could be seen as a system differentiation. These efforts are not only done by the state (system) but also by a number of non-state actors inside or outside the country (subsystem) through the awareness of being Indonesian, a new awareness of being a part of an independent country. The effort to introduce national identity is then give a crucial impact on the relations between counties.

Public Diplomacy at that time was administerred both by the nations or a number of non-state actors inside and outside the country. Meanwhile, the bilateral diplomacy was administerred through Diplomasi Perjuangan or also known as Sjahrir's diplomacy. The minimum beliefs among the Alliance Countries toward Soekarno and Hatta who assumed to cooperate with Japanese (Frances Gouda dan Thijs Brocades Zaalberg 2008, 124-125), led Sjahrir do a number of negotiation with the Dutch. This is not an easy way because some elites thought that what is done by Sjahrir had no nationalism based at all (Rosihan Anwar 1995, 117). Negotiating with the imperial is supposed to be a betrayal towards Indonesian's struggle. However, Sjahrir's effort finally yields in Linggarjati and Renville agreements, Roem Royen, and Round Table conference.

The diplomacy of independence signs the good effort of both state and non-state actors to maintain national identity of the new Indonesia as an independent country. Besides going through negotiation, the effort to win other countries' heart is also done by making other country believe in Indonesia through personal approach. Indonesia's diplomatic efforts in Egypt and Australia can show that the efforts made by state and non-state actors have equal role in gaining recognition of Indonesian independence

\section{Indonesia Searched for Recognition of Independence from Egypt and Arab Countries.}

Efforts to gain recognition of Indonesia's independence are carried out by both state and non-state actors. KH Agussalim as the young foreign minister then traveled diplomatically to several countries such as India, Egypt and Arab countries to conduct a series of talks to gain de facto recognition of Indonesia's independence. The diplomatic effort resulted in the first legally recognition of independence by Egypt and then followed by other countries such as Syria, Yemen, Arabian Saudia, and Iraq. KH. Agussalim is known as an accomplished negotiator because of his language skills, his open and sociable attitude (Ubain and Moein 1984, 157-158). His role as a diplomat during Indonesian independence was recognized as an important figure (Mohamad Roem 1978, 128).

In addition to diplomatic efforts made by the state, no less important diplomatic efforts undertaken by non-state actors in Egypt and Arab countries. This is explained by Fachir who identified, that the diplomacy was initiated and more done by Indonesian youngsters and students in Egypt. The formal ambassador of the government found that it was not easy to do so because the condition of Indonesia at that time was still busy with the struggle to fight against the Dutch that still wanted to impose Indonesia with military force (Fachir.A.M 2009; 24-25). Indonesia-Egypt relationship was getting more meaningful when a student from Java, Ismail Muhammad Al-Jawi founded Riwaq Jawi in Egypt after World War 1. The word Java was used at that time because at that time Java was used as the center of administration, education, culture, and export and import. Therefore, everything from Indonesia was called Jawi (Suranta Abd.Rahman 2007, 156). 
The small group was finally developed when Egypt government in 1923 gave a legal letter of permission for students from Java (Indonesia) to found an organization that moved in social and politics. The students' movement then published some politics magazines such as Seruan Al Azhar, Pilihan Timur, and Usaha Pemuda. The movements then founded the Union of Indonesia- Malaya Youngsters or Persatuan Pemuda Indonesia-Malaya (Perpindom) which was based on the awareness of the same root of Indonesia and Malaya and has the goal of rejecting cooperation with the collonialists. Besides in Egypt, the similar movements were also found in Arabian Saudia that is Pertindom (Persatuan Talabah Indonesia-Malaysia) and in Iraq that is Makindom (Majelis Kebangsaan Indonesia Malaya).

The name Indonesia was continually used after the independence as the names of the union of students and youths in Egypt Perhimpunan Kemerdekaan Indonesia (PKI). PKI had a mission to create the factual freedom of Indonesian citizen from the Dutch guardianship and gaining the factual and formal admission for the Independent Indonesia. They did some special approach to the politicians in Egypt and approaches to the mass media to actively spread the news about Indonesian Independence. Arabian community themselves could access the news about Indonesia through APB or the Arabian Press Board in which APB forwarded the news from Radio Republik Indonesia (RRI) in Yogyakarta. One of the stories in APB is the security situation and daily life of Indonesian citizen in Yogyakarta after the proclamation of Independence. APB also moved all Arabian newspapers to broadcast news entitled "The Troup of Betrayers will Visit Arabian Countries.", "Dutch Propagandists”, "Dutch Merchants" and "Dutch Propagandist" to face the Dutch propaganda that was aimed at obstructing Indonesian Diplomatic comissions.

The closeness of the PKI led by Muhammad Zein Hassan with academic groups and political parties attained a positive response. The support was shown by a student demonstration in front of the Dutch Embassy in Cairo against Dutch policy towards Indonesia. An Islamic organization, Al-Ikhwan Al-Muslimun led by Shaykh Hasan Al-Banna also showed a good response by raising public opinion through media coverage. He provided a broad opportunity for Indonesian students to write about Indonesia's independence to be disseminated either through local newspapers or large tabligh events. This organization was also member of the 'Indonesian Independence Defense Committee' set up in Cairo on 16 October 1945.

The Indonesian Independence Defense Committee or Lajnatud Difa'i 'an Indonesia headed by General Saleh Harb Pasya involved many Egyptian leaders as well as several other Arab countries. They produced a resolution which contained (1) boycotting dutch made goods in all over Arabian coutries; (2) stopping the diplomatic relationship between Arabian countries and Dutch; (3) closing harbours and airport in Arabian area to the ships and planes from Dutch (concretely done in Suez bypass); (4) forming health teams to help the victims of Dutch agressions. This resolution became the basis for the Indonesian Independence Defense Committee to deliver a note to the Egyptian government (Hassan 1980, 63-64).

The closeness of M. Zein Hassan with General Saleh Harb Pasya, the Secretary General of the Pan Arab Congress (which later became the Arab League) also gave an opportunity to him to read the PKI letter before the Arab League session on 31 October 1945. In the letter was conveyed that the situation in Indonesia is getting worse and look for the concrete support of the Arab states and the recognition of the independent 
Republic of Indonesia (AM Fachir 2009, 28-29).

While efforts through diplomacy were organized, demonstrations and boycotts were still underway. The Indonesian students and Egyptian youngsters organized the boycotts of Dutch ships that entered Suez straight as the reactions of the first agression in 1947. On August $9^{\text {th }}$ 1947, a group of Dutch ships arrived at Port Said. They were welcomed by a big number of motorboats and small motors that roaming in the water in purpose to hinder the motor boats owned by the foreign companies that wanted to supply drinking water and food to the Dutch ship.

A number of international institutions showed their supports both through the material and political aids. The red crescents also show simpathy by sending paramedics, medicines, and health equipments. Meanwhile, Arabic League, led by Abdurrahman Azzam Pasya, showed its huge simpathy to the effort of Republik Indonesia to seek for international acknowledgment. The problems faced by Arabian League itself were so hard, such as the problems of Palestina, Suez Canal, Sudan, and the problem of English and France Protectorate Army in Arabic countries. However, the attention toward Indonesia became the main priority. This was shown in the court of UN's Security Council in August 1946 in New York: the enterance of the problem of Indonesia in the court agenda. In that opportunity, Abdurrahman Azzam Pasya seeked for support from Indian government through the telegraph sent to the Prime Minister Jawaharlal Nehru to support Indonesia and ask him to bring the Indonesian case to the UN's Security Council. Besides, when RI's delegation led by Sutan Syahrir faced financial problem during their stay in New York, Abdurrahman Azzam Pasya lent 20 thousand US dollar which was taken from Mahmud Abu Al Fath, an editor of Egyptian Newspaper, Al Misry, which was returned five months later by Indonesian government (Mohammad Roem 1986, 72-72). The struggle of Indonesian diplomacy finally got the acknowledgment from Egypt followed by other Arabic countries. This condition made Dutch could not deny the agreements anymore that they had signed with Indonesian government.

\section{Indonesia Searched for Recognition of Independence from Australia.}

Attempts to gain recognition of identity as an independent country from Australia were not easy. Australia did not necessarily provide support when Ali Satroadjoyo asked for Australia to bring Indonesian independence issue at the UN. However, the long journey of a number of Indonesian workers in Australia working with worker union such as the Waterside Workers Federation (WWF) and the Australian Workers Union (AWU) succeeded in encouraging the Labor Party that controlled Australia at that time to care for Indonesia's independence struggle. The same ideas of democracy and antiimperialism united the worker union the in the same movement, opposed the Dutch policy towards Indonesia (George Margaret 1986, 21).

The struggle of Indonesian workers in Australia was incorporate at Komite Indonesia Merdeka or KIM which was established on September $1^{\text {st }} 1945$ in Brisbane, Australia. Soon after KIM was founded in Brisbane, ther was another foundation in Sydney, Melbourne, and MacKa and then KIM in Brisbane was agreed to be the center of the organization and then was called CENKIM or Central Komite Indonesia Merdeka (Anon n.d.) CENKIM consisted on Indonesian citizen who stayed in Australia who mostly there for working in the companies owned by the Indian Dutch government. From these people, there came a manifest that stated that, "reimposition of the 
undemocratic and ruthless Dutch rule over the people of Indonesia is not and never will be accepted by our people" (Sah-Hadiyatan Ismail 2011). This matter then became the base of the struggle to invite Indonesian people in Australia to help Indonesia in struggling for their basic rights, Independence.

Soon after releasing the manifest, an action of eating stoppage was done and followed by 85 Indonesian sailors. They came down from the ship that will sail to Indonesia that loaded ammunition and other warfare equipments. This action of protest made them got illtreatment as illegal migrants and sentenced to jail. Positive response was harvested on the action by the occurrence of Black Armada incident which was an effort of boycotting Dutch's Ships by the Harbor Worker Association in Brisbane, Sidney, Melbourne, and Fremantle. As a result, there were more than 400 Dutch's ships cannot continue their journey to Indonesia because there was no harbor worker helped. The harbour workers also do a demonstration in front of the Dutch office and diplomat with a big placard "Hands off Indonesia" (Anon 2015).

This was also supported by the Australian Communist Party (ACP) and the Communist leadership of the Australian Water Workers Union which banned Australian port workers on September 20, 1945 across the Australian port for loading goods on all Dutch ships sailing to the Indies. On September 26, 1945, the Federal Council decided a thorough strike against all Dutch ships in Australian ports. Despite the problem of boycotting Dutch ships, the Australian government tried to give the impression of impartiality, but the prolonged boycott of Dutch shipping was interpreted abroad as a sign that the Australian government was supporting Indonesia's independence (TM Hadi Tayeb 1996, 185-186). This action became a next strategic step by the making of a documentary film. The film was made based on cooperation between CENKIM and Joris Ivens entitled "Indonesia Calling” (Anon 2009).

Besides making a documentary film as a tool to tell an important event to the people of the world, CENKIM also published some articles about the condition in Indonesia. A 20 pages note, "Republic of Indonesia", was made as an effort to spread stories about Indonesian Independence. There was also 36 pages note "Merdeka" was arranged to tell the activities of supporters out side the country about the independence of Indonesia. Those notes were firstly published on August $17^{\text {th }}$, and distributed to the members of United Nations. The effort of distributing this information was opened and was done until America, Singapore, Colombo, India, Egypt, until England. However, communications with their colleagues in Indonesia was still done secretly.

The delegation of Australian representative, W. McMahon Ball on November $7^{\text {th }}, 1945$ went to Jakarta to ensure the situation of Dutch Indian shows the support of Australian government toward Indonesia. From the visit, it was stated that what happened in Indonesia was really a pure nationalist movement and Australy had an interest to arbitrate the new political elites behind the nationalis movements. For Australia, the new situation must get an immediate response because nevertheless Indonesia's posistion is very strategic for the security issue of Australia. Although England seemed not happy with Australian's decision, Australia even gave its support toward the independence of Indonesia in 1946 through Good Offices Committee and convincing UN security council. Soon Australia built its diplomatic and trade representative after LinggarJati Agreement in Indonesia. 


\section{Public Diplomacy post-Independence}

In the post-independence period until the end of the New Order, Indonesian public diplomacy was more dominated by the state. The identity pinned by the state places non-state actors (outside the state and the domestic public) in a passive role in all communication activities between systems. Nevertheless, their contribution in the effort made by the state is significant enough to the identity. In the era of the Old Order, as a country just out of colonialism, Indonesia tended to embed identity as an anti-imperialist state in order to maintain its existence in the international environment while maintaining inter-state relations. A number of public diplomacy was conducted in order to embed identity through the solidarity of developing countries. The domestic public was also mobilized to support this effort and placed them in passive roles. In the New Order era, Indonesia's internationally isolated condition and economically disadvantaged situation due to the high politic policies of the Old Order, prompted Indonesia to redefine itself as a low profile country. This implies a particular set of interests or preferences to particular actors (Ted Hopf 1998, 175) and has encauraged Indonesia to put the security and economic stability as a priority. It also encouraged Indonesia to build ASEAN as a manifestation of identity-sharing efforts and a return to UN membership. Like the old order, the domination of the state puts the non-state actors or the domestic public in a passive role. They are placed in cultural diplomacy aimed merely to introduce Indonesian identity as a multicultural country and to improve Indonesia's economy.

\section{Public Diplomacy in the Old Order: Anti Imperialis Diplomacy}

"Free and Active" became the choice of Indonesia as a country just out of colonialism. This foreign policy is a strategic choice to support Indonesia's new status as a newly independent and active country in opposing the colonization. Through KAA and the new emerging forces Indonesia builds solidarity with fellow ex-colonial countries. Meanwhile, non-state or domestic public actors are placed as passive subjects in cultural dan sports diplomacy. The Asian-African Conference (Konferensi Asia Afrika / KAA) in Bandung in 1955 itself was the initial process of the birth of the Non-Aligned Movement. Although it required a lot of funds, but the great opportunity was taken Indonesia to be able to win the prestige of foreign policy of Indonesia. Abdul Gani noted that KAA has had a positive impact on Indonesia's foreign policy. Indonesian foreign policy prestige rose, the name of Indonesia among foreign countries uphill, especially in Asia and Africa. Abdul Gani claimed to be a good host, in addition to overcoming all kinds of difficulties, Indonesia can create a socio-cultural political atmosphere, hospitality and enthusiasm of the people who very impressed the delegates (Roeslan Abdulgani 1981, 319).

In addition in convincing the international community through the implementation of KAA, Indonesia's efforts to embed its new identity as a neutral country is supported by the slogans made by Soekarno "Nefo" and "Oldefo". Oldefo or Old Established Forces refers to a group of imperialist capitalist countries and Nefo or New Emerging Forces as a group of oppressed nations. The background as a country once colonized for hundreds of years, guides the idea of Nefo to stay away from western countries that were colonialist countries in the past. It is this that brings Indonesia into confrontation with Malaysia which is considered a colonialist henchman because of its proximity to Britain and some of its defense policies. 
The identity as a country who opposed to the colonialist was also nurtured through a number of cultural missions. Cultural missions made by Soekarno became part of diplomatic efforts involving non-state actors. From 1957-196os, a number of cultural missions / cultural diplomacy were sent to friendly countries such as Pakistan, the Soviet Union, Czechoslovakia, Poland, Hungary, North Korea, the United States and Japan. The entire missions were financed by the state and led by president (Jennifer Lindsay and Maya H.T. Liem 2011, 227-228). Involving a large number of dance, music and dance artists, cultural missions sent to a number of countries are the main source of reference for other nations to get to know Indonesia. Culture is not just a social practice of society but culture becomes very political when it is framed in a cultural mission.

At the 1962 Asian Games, Soekarno conveyed the idea that Indonesia is in the middle of a Panca Muka revolution which means National, Political, Economic, Cultural and Sports or New Indonesia. The Panca Front Revolution was later revised to Dasa. This became a nation building effort for Soekarno which was stated when opening the Ganefo (Games of the New Emerging Forces) at the State Palace on November 8, 1963. From this speech the concept of sport was called the Nation and Character Building (Harsuki, 2002). Ganefo became one of Indonesia's efforts to show its true identity through sport. By taking the motto "Onward! No Retreat, the sports festival was attended by 2,200 athletes from 48 Asian, African, Latin American and Eastern European countries. Ganefo became one of Soekarno's lighthouse projects to show Indonesia's identity to the world. Indonesia provided a large budget to provide accommodation and transportation facilities for each participant at that time (Tulus Warsito and Wahyuni Kartikasari 2007, 122).

Sukarno believes that sport can be an important part of the nation's development and character. Ganefo became a real effort of the state in maintaining a new identity of Indonesia which is no longer a colony but a new state which is independent and equal to other nations in the world. It's not only a sports event but also a political stage for new countries (former colonies) to redefine their status internationally (Russell Field 2011, 4). Involving a large number of non-state groups covering sports and media, Ganefo was in fact able to attract the attention of other countries, especially the West, one of the articles published by Malayan Monitor from London entitled "A Historic Victory For Anti Imperalists” (Bayu Kurniawan and Septina Alrianingrum 2013, 193).

\section{Diplomacy of the New Order Era: Development Diplomacy}

The domestic situation and the unfavorable inter-state relations resulting from the high politicism of the Old Order era prompted Indonesia to redefine who it was to improve its existence in inter-country relationships. It brought Indonesia to a policy that prioritizes the economic field without forgetting the political stability that forms the basis for economic development. Foreign policy posture was more cooperative and close to the capitalist countries to support foreign aid and foreign investment projects (Mohd Noor Mat Yazid 2014, 9).

Efforts to restore Indonesia's identity as well as relations between the state were done immediately after Suharto came to power. Regional security stability became Indonesia's first step through a good neighborhood policy. Together with Malaysia, the Philippines, Singapore and Thailand, Indonesia drafted the Bangkok Declaration as the foundation of ASEAN. The Bangkok Declaration was a reinforcement for identity- 
sharing efforts based on geographical, historical, cultural and economic interests. Indonesia then immediately re-entered the UN member in September 1966. This became an important step of Indonesia in maintaining relations between countries because the release of Indonesia in 1964 from the UN actually made it isolated. Indonesia began to improve relations with western countries because only the West could meet the Indonesian economy at that time (Pudjiastuti 2008: 118). This step was not in vain because in the midst of the American Containment Policy, Indonesia was placed as a strategic country to stem the influence of communism. To that end, America itself provided some assistance through Kennedy's policy of putting "development aid was security assistance" (Mohamad Hery Saripudin 1994, 78).

On the other hand, economic policy had implications for security policies that tend to ignore respect for human rights. The policy towards Portuguese Timor, the Free Aceh Movement and the Malari 1974 event became part of a repressive security policy to secure pro-western economic policies. In order to maintain the identity of countries in favor of human rights, peace diplomacy was held. Caroll's research shows that UN peacekeeping missions can be an important part of a nation's public diplomacy. Relationships established by peacekeepers are able to change the way the public view in the military conflict area. At a certain level, peacekeepers must also manage their relationships with both local media and foreign media. They are one of the main news sources of the ongoing conflict story (Major Chad G. Carroll 2007). Zahidi's thesis noted that the policy of political and economic stability of the Old Order had consequences on a number of human rights issues and the sending of peacekeepers into an attempt to gain international sympathy (M. Syaprin Zahidi 2015).

The dominance of the country in this era wasn't far different from the Old Order Era. Non-state actors tend to play a passive role in efforts to nurture inter-state relations. They move through state-run diplomacy of cultural diplomacy and student exchange, cooperation in language and science cooperation. One of the prestigious efforts of the New Order in the practice of preserving the identity of the state was seen in the implementation of KIAS (Indonesian Cultural Exhibition in the United States) in 1990-1991. Prepared for almost 5 years, the idea of Mochtar Kusuma Atmaja Minister of Foreign Affairs of Indonesia at that time, claimed quite successfully attracted the interest of American society. Organized by Yayasan Nusantara Jaya, KIAS involves dance, music, sculpture, painting, batik as well as several national companies in terms of funding. KIAS became one of the many Indonesian cultural missions that placed non-state actors as partners of the state in organizing public diplomacy. The positive reaction to the implementation of the KIAS was the extension of the KIAS project from half a year to 1.5 years from September 16, 1990 to May 1, 1992. Almost all American local media, CNN, NBC, ABC, The Washington Post, Boston Herald, Atlanta Journal, Dallas Morning News, Philadelphia Inquirer, and some other media reviewing KIAS gave a positive response (Tulus Warsito and Wahyuni Kartikasari 2007, 150).

\section{Public Diplomacy Post-Reform}

Political reform in Indonesia which coincided with the changing of the global constellation had an impact on reform within the Indonesian Ministry of Foreign Affairs. Public diplomacy gets its place in the structure of the Ministry of Foreign Affairs. This sub-section shows that public diplomacy began to be recognized as an 
has encouraged openness in Indonesia's political climate. The development of such a democracy is colorful and interrelated in the implementation of Indonesian diplomacy, both at the regional and international levels, both bilaterally and multilaterally ( $\mathrm{Al}$ Busyra Basnoer 2013). The process of democratization became one of the important points of Indonesia's diplomacy. Thus, it is not only a result of domestic politics and also a tool for the state for better communication toward public and the government of other countries to cultivate mutual understanding (Ellen Huijgh 2016, 20-22).

Third, progressive interpret the identity of Indonesia which focuses on economic development efforts. In line with one of the functions played by Indonesian foreign policy during the reformasi period, it helps to stabilize the important economic program from overseas market. This is in Hassan Wirajuda's speech when explaining contemporary themes that are the basis of Indonesian diplomacy, one of which is the development of progressive development (Hassan Wirajuda 2006).

Efforts to embed a moderate, democratic and progressive Indonesian identity are pursued through a series of diplomatic activities involving more non-state domestic actors. These activities include Interfaith Dialog, Indonesian Arts and Culture Scholarship Program, The Young Ambassador Program, Public Policy Breakfast, Public Lecture, Bali Democracy Forum / BDF and others. This act is one form of recognition that foreign policy and diplomacy can no longer run alone without the support of the domestic public. In the midst of an enormous flow of information and communication access anyone can have an opportunity to influence and be influenced.

\section{Public Diplomacy: Non-State Actors Efforts in Building Moderate Identity.}

The state has provided ample space for non-state actors to support the state's efforts to express its identity to the international environment. A number of activities involving the domestic public are held in the belief that the public can be an effective diplomatic agent because they tend to be trusted by the public outside the country. La Porte through its intermestic non-state actors reminds that domestic dimensions in establishing inter-civil society relationships in different countries allow them to be present as mediators and work independently. Similarly, Gregory believes that the domestic dimension is not merely a tool of the state because they can act independently as international actors in understanding the culture, behavior and attitude in order to build and manage relations between countries. They are also capable of influencing ideas and mobilizing citizens for their own interests and values (Bruce Gregory 2011, 353).

Unlike in the past where the great dominance of the state placed the domestic public in the passive activities of public diplomacy, the domestic public had an indirect opportunity to show its roles in nurturing a moderate Indonesian identity. It can be found in Nahdhatul Ulama's work through its faith based diplomacy. Some of these efforts, for example, were carried out by NU by conducting ICIS (International Conference of Islamic Scholars) in 2004. The ICIS principle of thought is the mobilization of moderate thought and nationalism. Moderation in question is the balance between faith and tolerance, while liberal, tolerance reduces faith, while the extreme does not give tolerance space (KH Hasyim Muzadi 2010). NU is also active in mediating the conflict in Pattani, Thailand (Walker 2009) and encourage peace in Syria (Okezone 2016). It can be interpreted as an inter-state peace effort initiated by a domestic organization by putting forward the principles of Islam as the religion of 
important tool in the state's efforts to maintain self-identity in international relations. The issue of terrorism seems to be quite influential in the building of identity pinned by the Ministry of Foreign Affairs, moderate, democratic and progressive. In public diplomacy built by the state, non-state actors are given ample space in an effort to communicate that identity to the governments of other countries as well as to the international public. However, in practice a number of other non-state actors also organize efforts to maintain relations between citizens between countries by sharing ... identity. Through the autonomous identity found in culture, public diplomacy efforts can be found in the practices of non-state actors in cultural cooperation.

\section{Public Diplomacy: The System of Communication Efforts toward International Environment through "moderate, democratic and progressive" narratives.}

The change in international world and democratic wave inside led to the reform in the body of the Foreign Affair Ministry in which there is the foundation of Directorate of Public Diplomacy. The other importance changes are the enforcement of the direction of public diplomacy in supporting the foreign affair politics, namely: (a) the empowerment of Indonesian moderate citizens, (b) Developing people to people contact, (c) Information Dissemination of foreign politics, (d) Embracing and Influencing the publics inside and outside the country, (e) Collecting the suggestions and ideas for administerring the foreign politics. In response to changes in international discourse dominated by the issue of terrorism, public diplomacy is mainly led to: (a) Performing the new face of Indonesia that is moderate, democratic, and progressive, (b) developing diplomacy constituent by collaboration, administering and embracing all stakeholders of foreign relations interests (A. Saefudin Ma'mun 2009).

The Indonesian identity laid in a moderate, democratic and progressive narrative was designed by Hassan Wirajuda to determine the direction for Indonesian public diplomacy. First, moderate is chosen as an image that is formed due to international issues that strongly cornering Islam, while Indonesia itself is an Islamic country. Bush's speech following the September 11 tragedy referred to establish perceptions of the event as a very evil act of terror and the development of common enemies (Debra Merskin 2004, 160). The situation was certainly a consideration for Indonesia which placed in the second tier of countries suspected of being a hotbed of terror by the Americans (Peng Claire Bai 2008). The word moderate is taken as an identity that refers to moderate Islam. Moderate Islam understood as a tolerant Islam, peace, balance and prioritizes dialogue in solving problems (Andri Hadi 2009, 167). General understanding can not be separated from the 3 factors that initiate the formation of moderate Islam that is pluralism, modernization and democracy (Lelly Andriasanti 2012, 63). The first official statement abiut moderate Islam was made by Foreign Minister Hassan Wirajuda before the General Assembly on 15 November 2001 which discussed the compatibility between Islam and Indonesian democracy. Gradually, the term moderate Islam was introduced in Indonesian foreign policy. Through oral exposure that began in 2004, Hassan Wirajuda stressed the obligation of Indonesia as the world's largest Muslim country to be able to project the true face of Islam, Islam as rahmatan lil alamin (N. Hassan Wirajuda 2004).

Secondly, democratically elected as an identity embedded in Indonesian public diplomacy to build perceptions about Indonesia's new identity as a democratic country and always maintain the values of democracy. The great influence of reform in 1998, 
rahmatan lil alamin (Andi Purwono 2013). Efforts by these domestic organizations indirectly become a public diplomacy for Indonesia. Trust and positive response is shown by the government and the people of Thailand itself which then inaugurated PCINU Thailand (formerly called Pattani Darussalam).

\section{Conclusion}

Public diplomacy as an effort to maintain the existence of countries in the international environment has been done both by state and non-state actors since public diplomacy as a formal institution had not been established. The effort is not merely a communicative action but rather, it aims to foster mutual understanding by sharing identity. International discourse and domestic politics contribute to shaping the Indonesian identity that guides it in particular action preferences. Meanwhile, non-state actors show their significant role even that are not always in the same ways.

Following Indonesia's diplomatic journey in three periods, the role of non-state actors in diplomacy fluctuated. In the period of independence, they appear active and independent in influencing relations through the new Indonesian identity as an independent country. Together with public diplomacy hel by state, non-state actors encourage academic groups and politicians to influence the Egyptian government and international agencies in supporting Indonesian independence.

In the post-independence period, the non-states actors's role tended to be passive because of the state domination. Nevertheless, the role of non-state actors in supporting efforts to share their identity and maintain inter-state relations is still significant. The old order succeeded in realizing its cultural and sport diplomacy as part of its efforts to maintain its anti-imperialist identity by mobilizing the solidarity of anti-imperialist countries. Meanwhile, the New Order embodies a more low-profile face through development diplomacy.

During the reform period in which public diplomacy gains its place within the body of the Ministry of Foreign Affairs, non-state actors also have a wider opportunity to support the country's activities in sharing its identity as a moderate, democratic and progressive Indonesia. Such an opportunity is practiced either in the design of public diplomacy of the country or independently. There is a domestic group capable of organizing efforts to maintain the identity of Indonesia as a moderate country independently. As well as Nahdhatul Ulama, this domestic non-state actor has their own fund and network which built independently without government intervention. The beliefs of other countries are a measure of their success in maintaining the identity of the state and relations between countries.

\section{References}

\section{Book and Chapters in Book}

Anwar, Rosihan. 1995. Soebandrio Sastrosatomo, Pengemban Misi Politik. Jakarta: Grafiti. Berridge, GR. 2010. Diplomacy Theory and Practice 4th ed. Plagrave Macmillan: Hampshire. 
Fachir, A.M. 2009. Jauh di Mata dekat di Hati: Potret Hubungan Indonesia-Mesir. KBRI Cairo bekerja sama dengan Sumber Aksara Yogyakarta.

Hassan, M. Zein LC. 1980. Diplomasi Revolusi Indonesia di Luar Negeri. Jakarta: Penerbit Bulan Bintang.

Hopf, Ted. 2002. Social Construction of International Politics: Identities \& Foreign Policies, Moscow, 1955 and 1999. Ithaca, NY and London: Cornell University Press.

Huijgh, Ellen. 2016. The Public Diplomacy of Emerging Powers. Part 2: The Case of Indonesia. Los Angeles: Figueroa Press.

Leonard, Mark, Catherine Stead and Conrad Sweming. 2002. Public Diplomacy. London: The Mezzanine.

Lindsay, Jennifer and Maya H.T. Liem. 2011. Ahli Waris Budaya Dunia: Menjadi Indonesia 1950-1965. Jakarta: Pustaka Larasan.

Luhmann, Niklas. 1995. Social System. California: Stanford University Press.

Ma'mun, A. Saefudin. 2009. Citra Indonesia di Mata Dunia Gerakan Kebebasan Informasi dan Diplomasi Publik. Bandung: TrueNorth.

Moracsik, Andrew. 2993. "Integrating International and Domestic Theories of International Bargaining." Dalam Peter R. Evans, Harold K. Jacobson dan Robert D. Putnam (ed.). Introduction toInternational Bargaining and Domestic Politics: Double-Edged Diplomacy. University of California Press.

Nau, Henry R. 2009. Perspective on International Relations, Power, Institution, Ideas $2^{\text {nd }}$. Washington: CQ Press.

Roem, Mohamad. 1978. " Pemimpin Adalah Menderita: Kesaksian Haji Agus Salim”. In Taufik Abdullah, Aswab Mahasin, Daniel Dhakidae (ed). Manusia Dalam Kemelut Sejarah. Jakarta: LP3ES.

Roem, Mohamad. 1986. Diplomasi: Ujung Tombak Perjuangan RI. Jakarta: Gramedia.

Snow, Nancy. 2009. "Rethinking Public Diplomacy". In Nancy Snow dan Phillip M. Taylor. Routledge Handbook of Public Diplomacy. Madison Avenue: Routledge.

Tuch, Hans. 1990. Communicating with the Worlds: US Public Diplomacy Overseas. New York: St. Martin.

Ubain, B.A. and Mohammad Moein. 1984. Seratus Tahun Haji Agus Salim. Jakarta: Sinar Harapan.

Warsito Tulus and Wahyuni Kartikasari. 2007. Diplomasi Kebudayan: Konsep dan Relevansi Bagi Negara Berkembang: Studi Kasus Indonesia. Yogyakarta: Penerbit Ombak.

Wirajuda, Hassan. 2010. "Kedekatan Alamiah antara PR dan Diplomasi”. In Silih Agung Wasesa dan Jim Macnamara.Strategi Public Relation. Jakarta: PT Gramedia Utama.

\section{Journal and Online Journal}

Abd. Rahman, Suranta. 2007. "Diplomasi RI di Mesir dan Negara-Negara Arab pada Tahun 1947". WACANA, 9. (2): 154-172.

Brian Hocking. 1998. “The End(s) of Diplomacy”. International Journal 53 (1).

Chen, Po-Chi. 2012. "Cyber Public Diplomacy as China's Smart Power Strategy in an Information Age: Case Study of Anti-Carrefour Incident in 2008". International Journal of China Studies. 3 (2).

Cowan, Geoffrey and Amelia Arsenault. 2008. "Moving from Monolog to Dialogue to Collaboration: The Three Layers of Public Diplomacy" Annals of the American Academy of Political and Social Science, 616.

Gregory, Bruce. 2011. “American Public Diplomacy: Enduring Characteristics, Elusive 
Transformation”. The Hague Journal of Diplomacy. 6 (3/4).

Hadi, Andri. 2009."Demokrasi Bukan Produk Barat”. Jurnal Diplomasi 1(1).

Hopf, Ted. 1998. "The Promise of Constructivism in International Relations Theory". International Security 23(1).

Kurniawan, Bayu and Septina Alrianingrum. 2013. "Ganefo sebagai Wahana dalam Mewujudkan Konsepsi Politik Luar Negeri Soekarno 1963-1967”. AVATARA, e-Journal Pendidikan Sejarah, 1(2).

La Porte, Teresa. 2012. "The Impact of 'Intermestic' Non-State Actors on the Conceptual Framework of Public Diplomacy". The Hague Journal of Diplomacy 7.

Merskin, Debra. 2004. "The Construction of Arabs as Enemies: Post September 11 Discourse of George W. Bush". Mass Communication and Society 7(2).

Muzadi, KH. Hasyim. 2010. "ICIS, Islam Moderat dan Interfaith Dialogue". Tabloid Diplomasi. 32(III).

Purwono, Andi. 2013. "Organisasi Keagamaan dan Keamanan Internasional". Jurnal Politik Profetik 2(2).

Rahman, Suranta Abd. 2007. "Diplomasi RI di Mesir dan Negara-Negara Arab pada Tahun 1947”. WACANA, 9(2).

Yazid, Mohd. Noor Mat. 2014. "The Indonesian Economic Development after 1965: Developmental State, Radical Politics \& Regional Cooperation”. SOP TRANSACTIONS ON ECONOMIC RESEARCH, 1(3).

Zahidi, M. Syaprin. 2015. "Double Standard Indonesia dalam Diplomasi Kemanusiaan". Jurnal Insignia, 2(1).

\section{Online Article}

Anon. 2009. Joris Ivens' Historic Short Film: 'Indonesia Calling”. The Jakarta Post. [online] http://www.thejakartapost.com/news/2009/o8/16/joris-ivenso39-historicshort-film-indonesia-callingo39.html. [accesed December 27, 2016].

Anon. 2015. "Mesir Negara Pertama yang Secara Resmi Mendukung Kemerdekaan Indonesia”.Suara Darussalam. [online] http://www.suaradarussalam.com/2015/o8/ mesir-negara-pertama-yang-secara-resmi.html. [accesed December 27 2016].

Anon. 2015. "Peristiwa 'Black Armada' Bukti Dukungan Warga Australia di Awal Kemerdekaan RI". detikNews. [online] http://news.detik.com/australia-plusabc/2999019/peristiwa-black-armada-bukti-dukungan-warga-australia-di-awalkemerdekaan-ri. [accesed Maret 15, 2017].

Anon. 2015. "Dekati Otoritas Thailand, Muslim Pattani Minta Dukungan NU". [online] http://www.nu.or.id/post/read/59778/dekati-otoritas-thailand-muslim-pattani-minta-dukungan-nu. [accesed March 13, 2017].

Anon. 2016. "Rajut Islam Nusantara, PCIMU Thailand Resmi Berdiri”. NU Online. [online] www.nu.or.id. [accesed March 13 2017]

Anon. n.d. "Catatan Seorang Perintis Kemerdekaan". http://www.sejarah-bondan.net/ content/Perintis.pdf. [accesed December 27, 2016].

Bai, Peng Claire. 2008. "Terrorism and the Future of U.S. Foreign Policy in Southeast and Central Asia”. International Affairs Review. [online] in http://www.iar-gwu.org/ node/24 [accesed May 27, 2017]

Basnoer, Al Busyra. 2013. "demokrasi dan diplomasi Indonesia”. SindoNews.Com [online] in http://nasional.sindonews.com/read/808773/18/demokrasi-dan-diplomasi-indonesia-1385084227/2. [accesed September 1, 2016].

Ismail, Sah-Hadiyatan. 2011. "Australia and the Indonesian Independence". Asian Social Sciences.7(5): 152 [online] http://citeseerx.ist.psu.edu/viewdoc/download;jsession- 
id=CEB8883392ECB79A34E7DBB9A41A6AD6?doi=10.1.1.653.8216\&rep=rep1\&type $=$ pdf. [accesed Desember 27, 2016].

Malik, Sajjad. 2014. "Track II Diplomacy and Its Impact on Pakistan India Peace Process" [online] in http://issi.org.pk/wp-content/uploads/2014/o6/1339998912_67212139. pdf. [accesed December 26, 2016].

Saripudin, Mohamad Hery. 1994. "The Effecs and The Relations of Foreign Aid: A Case Study of Indonesia and Its two Largest Donors, The United States and Japan”. Master Thesis. Saint Mary's University, Halifax, Canada [online] in http://mobile.library2. smu.ca/bitstream/handle/o1/22668/saripudin_mohamad_h_masters_1994. PDF?sequence $=1$ \&isAllowed $=y$. [accesed January 3, 2017].

\section{Others}

Abdulgani, Roeslan. 1981. "Sekitar Konperensi Asia-Afrika dan Maknanya bagi Politik Luar Negeri Indonesia”. Analisa, 4.

Andriasanti, Lelly. 2012. Identitas Islam Moderat dalam Kebijakan Luar Negeri Indonesia. Tesis. Universitas Indonesia.

Carroll, Major Chad G. 2007. "The U.S. Army Public Diplomacy Officer: Military Public Affairs Officers' Roles in the Global Information Environment" Master Thesis. The University of North Carolina, Chapel Hill [online] https://cdr.lib.unc.edu/ indexablecontent/uuid:beeb7af5-a854-4be8-a3fb-9cbacba73778. [accesed January 3, 2017]

Falahi, Ziyad. 2012. "Kebijakan Luar Negeri dalam Era Liberalissasi Informasi: Studi Kasus Semboyan Million Friends Zero Enemy Pemerintahan Soesilo Bambang Yudhoyono”. Tesis. Universitas Indonesia.

Field, Russell. 2011. "The Olympic Movement's Response to the Challenge of Emerging Nationalism in Sport: An Historical Reconsideration of GANEFO". Faculty of Kinesiology and Recreation Management. University of Manitoba. Winnipeg, Canada. [online]https://doc.rero.ch/record/24926/files/Russell_Field_-_report.pdf.[accesed November 6, 2016].

Gouda, Frances dan Thijs Brocades Zaalberg. 2008. American Visions of the Nethrelands East Indies/Indonesia: USForeign Policy ang Indonesia Nationalism, 1920- 1949.

Harsuki. 2002. "Olahraga dan Integrasi Bangsa”. Seminar Nasional, Ditjen Olahraga Jakarta.

Hocking, Brian et. all. 2012. Futures for Diplomacy. Integrative Diplomacy in the $21^{\text {st }}$ Century. Report No.1. Netherlands Institute of International Relations 'Clingendael'

Kupinska, Karolina. 2010. Contemporary Multitrack Diplomacy Across the Taiwan Strait. Thesis pada Ming Chuan University. Taiwan.

Riordan, Shaun. 2004. "Dialogue-based Public Diplomacy: A New Foreign Policy Paradigm?” DISCUSSION PAPERS IN DIPLOMACY.No. 95. Netherlands Institute of International Relations 'Clingendael'.

Wirajuda, Hassan. 2004. "Refleksi Tahun 2003 dan proyeksi Tahun 2004”. Paparan singkat yang disampaikan di Kementrian Luar Negeri Indonsia tanggal 6 January 2004.

Wirajuda, Hassan. 2006. Speech "Membangun Citra Indonesia Demokratis, Moderat dan Progresif: Konsolidasi Soft Power dan Aset Politik Luar Negeri RI". Bandung, $6^{\text {th }}$ December 2006. In PEWARTA Departemen Luar Negeri, Tahun XXXIII No. 116 (Oktober-Desember 2006). 